\title{
TWO METHODS OF SAMPLE PREPARATION FOR ANALYSIS OF NON-ORTHO AND MONO-ORTHO PCB CONGENERS IN THE MUSCLES OF SELECTED FISH SPECIES
}

\author{
Agata WITCZAK$^{*}$ and Monika CHLEWINSSKA
}

\author{
Division of Toxicology, Agricultural University of Szczecin, Poland
}

\begin{abstract}
Witczak A., Chlewińska M. 2008. Two methods of sample preparation for analysis of non-ortho and mono-
\end{abstract} -ortho PCB congeners in the muscles of selected fish species. Acta Ichthyol. Piscat. 38 (1): 63-71.

Background. Polychlorinated biphenyls (PCBs) are persistent organic pollutants widespread in the environment. Their ability to accumulate in living organisms leads to food contamination, which is the main route of human exposure to PCBs. During analytical procedure of PCB residue determination, losses of these compounds may occur, which contribute to obtaining underestimated analytical results. Adequate analytical method of chlorobiphenyls determination should be applied to avoid the losses and obtain high recoveries and furthermore to enable accurate estimation of the risk of consuming contaminated food. Especially fish, due to the high bioaccumulation, may contain considerable amounts of these compounds. The aim of this study was to determine if the method of sample preparation influences the recovery of non-ortho (PCB 77, 81, 126, 169) and mono-ortho (PCB $105,114,156,157)$ PCB congeners in selected fish species.

Materials and Methods. To prepare samples for chromatographic determination (HP 6890/5973 GC MS) two methods were applied. Fish muscle tissues were dried by rubbing in a mortar with anhydrous sodium sulphate or freeze dried (lyophilised) (LyoLAB 3000). The samples were fortified with a known amount of internal standard (decachlorobiphenyl), and some were additionally fortified with the standard solution of analysed PCB congeners. Results. Internal standard recoveries ranged from $57.61 \pm 1.21 \%$ to $88.76 \pm 4.03 \%$ in freeze-dried samples, and from $63.81 \pm 5.11 \%$ to $97.50 \pm 6.14 \%$ in samples rubbed with anhydrous sodium sulphate. Following lyophilisation, recoveries of analysed PCB congeners varied from $68.88 \pm 11.74 \%$ for PCB 157 to $79.18 \pm 12.33 \%$ for PCB 114. In the samples rubbed with anhydrous sodium sulphate the lowest recovery was determined for PCB $77(72.40 \pm 12.34 \%)$, the highest being typical for PCB $156(83.47 \pm 12.86 \%)$. Following lyophilisation, toxic equivalents (TEQs) for the examined fish species ranged from $0.0050 \mathrm{ng}$-TEQ $\cdot \mathrm{g}^{-1}$ dry weight in salmon to $0.0299 \mathrm{ng}$-TEQ $\cdot \mathrm{g}^{-1}$ dry weight in mackerel. Following rubbing with anhydrous sodium sulphate the highest toxic equivalent $\left(0.0326 \mathrm{ng}\right.$-TEQ $\cdot \mathrm{g}^{-1}$ dry weight $)$ was calculated for mackerel, and the lowest for salmon (0.0055 ng-TEQ $\cdot \mathrm{g}^{-1}$ dry weight).

Conclusion. The research has demonstrated that in most cases the results obtained with both methods have not differed significantly $(P<0.05)$, although freeze drying resulted in slightly higher losses of PCB congeners. Despite of smaller recoveries, freeze drying can be applied because of solvent saving and easier sample preparation.

Keywords: non-ortho and mono-ortho PCB congeners, freeze drying, fish

\section{INTRODUCTION}

Polychlorinated biphenyls (PCBs) are aromatic halide compounds, which consist of two phenyl rings saturated with chloride atoms. Specific physico-chemical properties of PCBs (low electrical conductivity, high thermal conductivity, high lipid solubility, low flammability) contributed to their wide industrial application, especially in electrotechnics. However, their slow biodegradation and high persistency resulted in accumulation of the compounds in various compartments of the environment for long periods, even years (Brzeziński 2002). PCBs have permeated to food products and their biggest amounts are accumulated in aquatic animals, especially fish (Atuma et al. 1998, Ciereszko 2002, Ciereszko and Witczak 2002, Falandysz et al. 2002, Ciereszko et al. 2004, Baars et al. 2004, Davis et al. 2007).

In the recent years, a decreasing trend has been observed for PCBs levels in fish from the Netherlands's inland waters, the Belgian continental shelf and the North Sea. However, in fish from the Netherlands's inland waters, concentrations of the more highly chlorinated congeners have remained on a constant level. No changes have been observed in the concentrations of chlorobiphenyls in fish from the Arctic Sea and the Baltic Sea (Paasivirta et al. 1994, Roose et al. 1998).

\footnotetext{
* Correspondence: Dr Agata Witczak, Katedra Toksykologii, Wydział Nauk o Żywności i Rybactwa, ul. Papieża Pawła VI 3, 71-459 Szczecin, Poland, phone: +4891 4250403, fax: +4891 4871962, e-mail: agaw@tz.ar.szczecin.pl
} 
During analytical procedure of PCB residues determination losses of these compounds may occur, which contribute to obtaining underestimated analytical results. Adequate analytical method of chlorobiphenyls determination should be applied to avoid the losses and obtain high recoveries, and furthermore to enable accurate estimation of the risk of consuming contaminated food.

a) PCB 77 (3,3', 4,4' -tetrachlorobiphenyl)

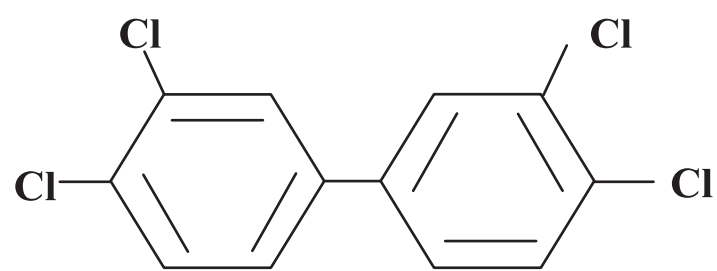

c) PCB $126\left(3,3^{\prime}, 4,4^{\prime}\right.$, 5-pentachlorobiphenyl)

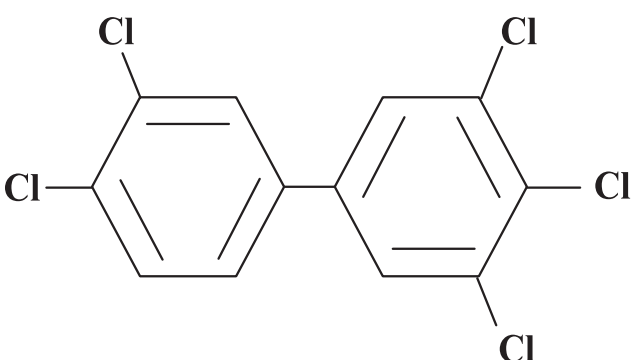

e) PCB 105 (2,3,3',4,4'-pentachlorobiphenyl)

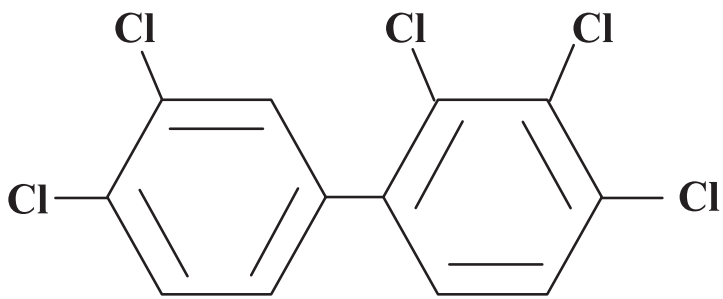

g) PCB 156 (2,3,3',4,4',5-hexachlorobiphenyl)

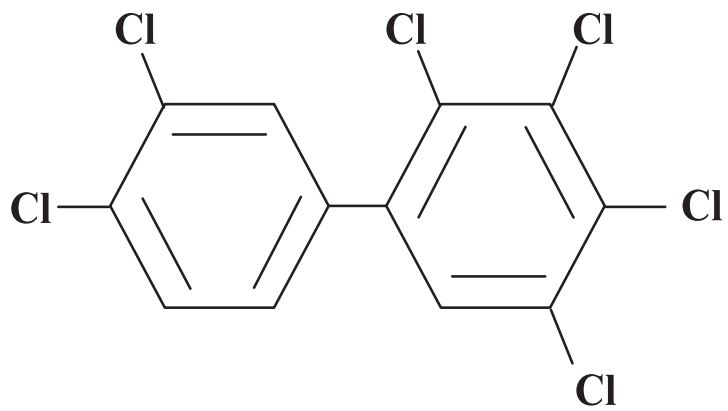

The aim of this study was to determine if the method of sample preparation influences the recovery of nonortho (PCB 77, 81, 126, 169) and mono-ortho (PCB 105, $114,156,157)$ PCB congeners (Fig.1) in the muscles of selected fish species. Two methods of sample drying have been applied: rubbing in a mortar with anhydrous sodium sulphate and freeze drying.

b) PCB 81 (3,4,4',5-tetrachlorobiphenyl)

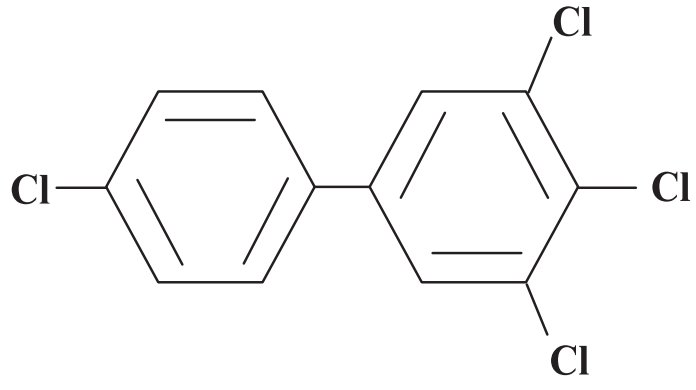

d) PCB 169 (3,3',4,4',5,5'-hexachlorobiphenyl)

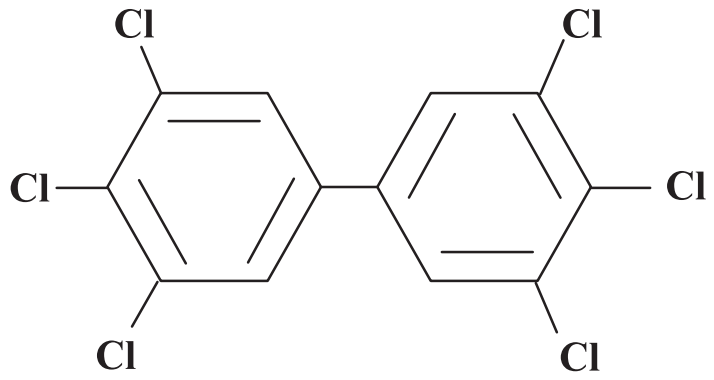

f) PCB 114 (2,3,4,4',5-pentachlorobiphenyl)

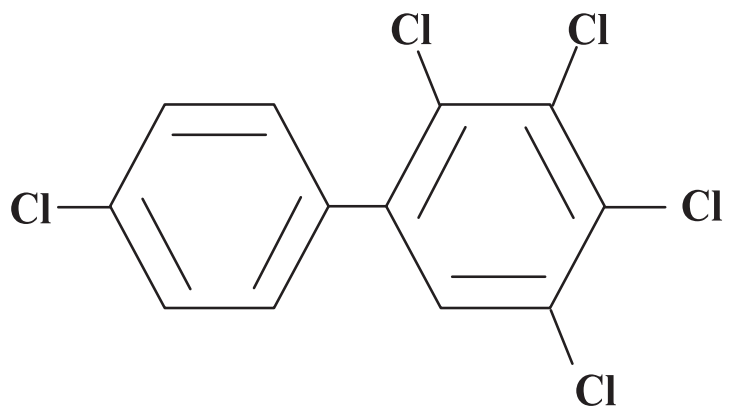

h) PCB 157 (2,3,3',4,4',5'-hexachlorobiphenyl)

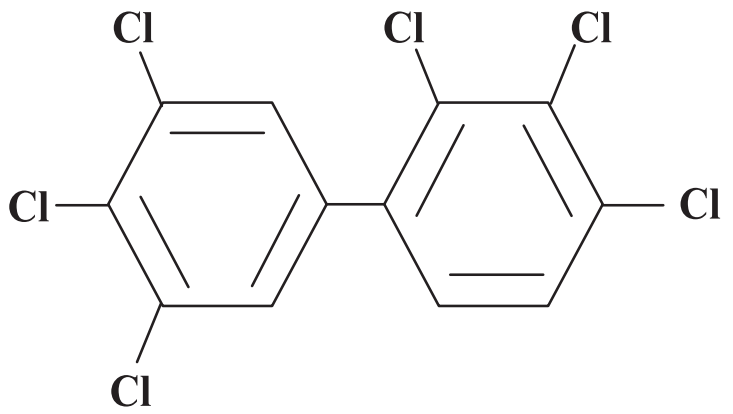

Fig. 1. Chemical structures of non-ortho (a, b, c, d) and mono-ortho (e, f, g, h) PCB congeners 


\section{MATERIALS AND METHODS}

The study involved muscle tissue collected from edible portions of flounder, Platichthys flesus (L.); Atlantic halibut, Hippoglossus hippoglossus (L.); Atlantic mackerel, Scomber scombrus L.; Atlantic herring, Clupea harengus L.; and Atlantic salmon, Salmo salar L. The fish were bought as skinned fillets at retail in Szczecin in March 2006.

The fish tissues were blended in a homogenizer and analytical samples were taken for analyses of PCBs (10 g) and dry mass content $(1 \mathrm{~g})$. To examine recoveries of the analyzed compounds, the samples were fortified with a known amount of the internal standard solution Pesticides Surrogate Spike Mix (SUPELCO, USA, 4-8460), which was a solution of decachlorobiphenyl and 2,4,5,6 - tetrachloro-m-xylene (100 $\mu \mathrm{L}$ of concentration $0.32 \mathrm{ppm})$. Some samples were additionally fortified with the standard solution of 8 PCB congeners (PCB Mix-8 CERTAN, LGC Promochem, NE 90152) (50 $\mu \mathrm{L}$ of concentration $0.1 \mathrm{ppm})$. To prepare samples for gas chromatographic determination two methods were applied. Fish muscle tissues were dried by rubbing with anhydrous sodium sulphate or freeze dried (lyophilised). The samples were prepared according to the flowchart (Fig. 2). Operating conditions of the chromatographic analysis were, as follows: column temperature program: $130^{\circ} \mathrm{C}$ (hold $0.5 \mathrm{~min}$ ) $\rightarrow$ increase rate $7^{\circ} \mathrm{C} \cdot \mathrm{min}^{-1} \rightarrow 200^{\circ} \mathrm{C}$ (hold $5 \mathrm{~min}$ ) $\rightarrow$ increase rate $4^{\circ} \mathrm{C} \cdot \min ^{-1} \rightarrow 280^{\circ} \mathrm{C}$ (hold $10 \mathrm{~min}$ ); single sample analysis time: $45.5 \mathrm{~min}$; carrier gas (helium); flow rate: $1.1 \mathrm{~mL} \cdot \mathrm{min}^{-1}$; pressure: $0.18 \mathrm{MPa}$ (26.5 psi); detector MSD (HP 5973); column: HP-5MS (60.0 m; ID $250 \mu \mathrm{m}$; film thickness $2.25 \mu \mathrm{m})$.

Statistical treatment of the results was performed using the STATISTICA ${ }^{\circledR} 6.1$ software. The statistical analysis included analysis of variance (ANOVA) and determination of correlation and variability coefficients. Toxic equivalents (TEQs) were calculated as a sum of products of the determined PCB concentrations in the analyzed samples and their toxic equivalency factors (TEFs) (Safe 1994, Van den Berg et al. 2006).

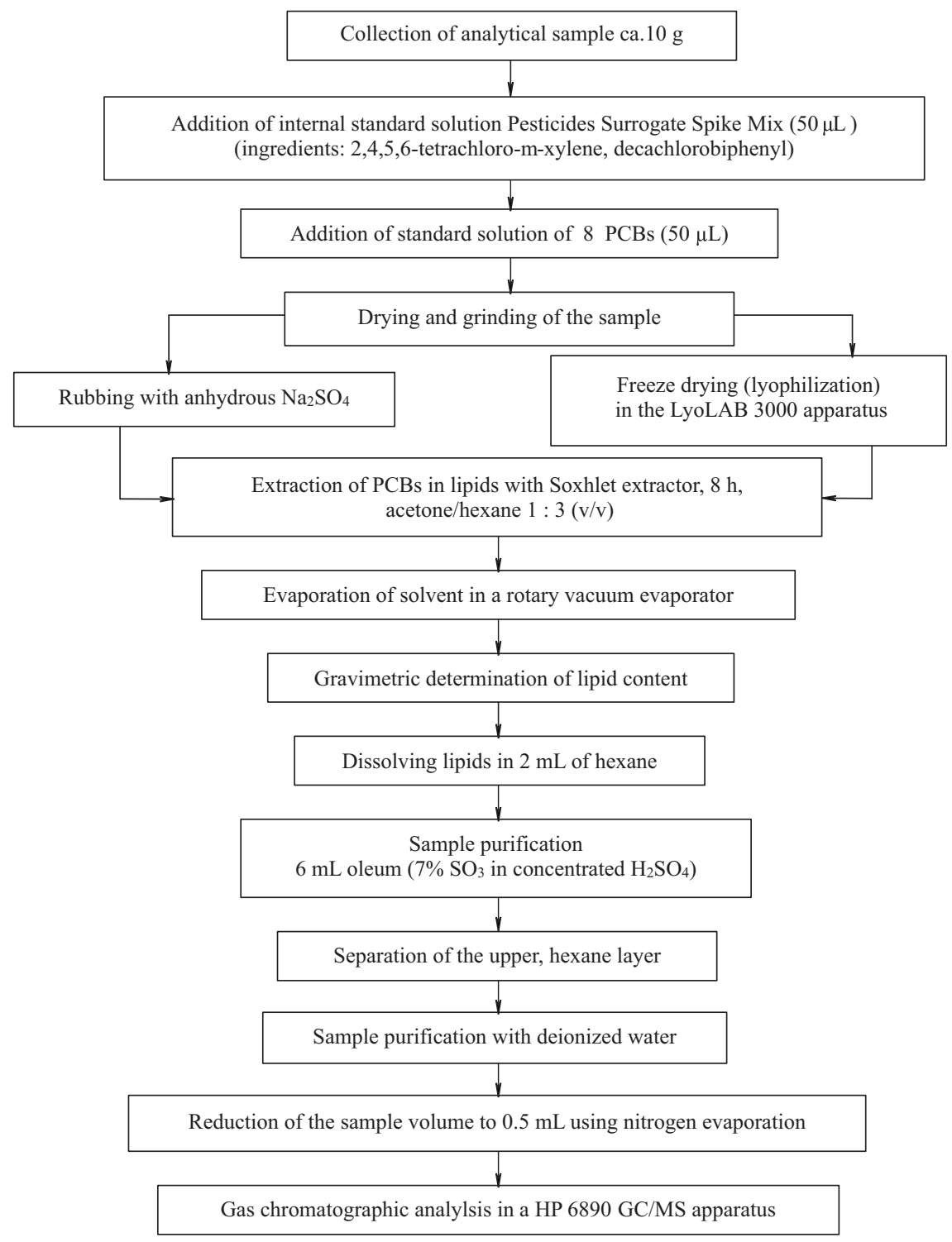

Fig. 2. The flowchart of PCB analysis in fish samples 


\section{RESULTS}

Raw muscle tissue of the examined fish contained from $25.3 \%$ to $37.2 \%$ of dry weight, and from $3.09 \%$ to $17.3 \%$ of lipids. After freeze drying, the dry weight content in the samples ranged from $99.0 \%$ to $99.9 \%$ (Table 1 ).

Concentrations of the toxic PCB congeners (non-ortho: PCB 77, 81, 126, 169 and mono-ortho: PCB 105, 114, $156,157)$ in the fish muscle tissue samples, dried with two different methods, are presented in Tables 2 and 3. The data were calculated as arithmetic means and standard deviations of PCB concentrations reported as $\mathrm{ng} \cdot \mathrm{g}^{-1}$, on a dry or lipid weight basis.

The determined PCB concentrations ranged from 0.029 $\pm 0.0034 \mathrm{ng} \cdot \mathrm{g}^{-1} \mathrm{~d}$.w. (dry weight) (PCB 157, salmon) to $5.035 \pm 0.0207 \mathrm{ng} \cdot \mathrm{g}^{-1} \mathrm{~d}$.w. (PCB 157, mackerel) in the lyophilisates and from $0.025 \pm 0.0021$ (PCB 126, salmon) to $5.118 \pm 0.0547 \mathrm{ng} \cdot \mathrm{g}^{-1} \mathrm{~d}$.w. (PCB 157, mackerel) in the samples rubbed with $\mathrm{Na}_{2} \mathrm{SO}_{4}$. Having calculated PCB concentrations in samples prepared with either the first or the second method, the largest concentrations were found for PCB 157 in mackerel (above $5 \mathrm{ng} \cdot \mathrm{g}^{-1} \mathrm{~d} . \mathrm{w}$.), while the lowest were observed for PCB 126 in all the examined fish species (Table 2, 3).

Recoveries of the internal standard (surrogate) in the freeze dries samples ranged from $57.6 \%$ for herring to $88.8 \%$ for salmon, and in the samples rubbed with anhydrous $\mathrm{Na}_{2} \mathrm{SO}_{4}$ from $63.8 \%$ for halibut to $97.5 \%$ for salmon (Fig. 3).

Comparison of the results of analytical samples and fortified samples determinations revealed that mean recoveries of PCBs ranged from $59.2 \%$ to $102.1 \%$. In the freeze dried samples the recoveries were from $68.9 \%$ (PCB 157) to $79.2 \%$ (PCB 114), and in the samples rubbed with $\mathrm{Na}_{2} \mathrm{SO}_{4}$ - from $72.4 \%$ (PCB 77 ) to $83.5 \%$ (PCB 156) (Fig. 4). Significance of differences among the obtained results was tested with Student's $t$-test.

Statistically significant differences $(P \leq 0.05$; Student's $t$-test for independent samples, $n=5$ ) between PCB concentrations in the samples prepared with the above mentioned methods were not observed. Only in herring, the differences were observed for all the examined PCB congeners, excluding PCB 81.

Table 1

Dry weight and lipid content in raw and freeze dried samples of muscle tissue of various marine fish species

\begin{tabular}{lcccc}
\hline \multirow{2}{*}{$\begin{array}{l}\text { Fish } \\
\text { species }\end{array}$} & $\begin{array}{c}\text { Dry weight } \\
\text { in raw sample }\end{array}$ & $\begin{array}{c}\text { Lipids } \\
\text { in raw sample }\end{array}$ & $\begin{array}{c}\text { Dry weight after } \\
\text { freeze drying }\end{array}$ & $\begin{array}{c}\text { Lipids } \\
\text { in dry weight }\end{array}$ \\
\cline { 2 - 5 } Mackerel & $37.24 \pm 0.96^{*}$ & $17.34 \pm 0.54$ & $99.94 \pm 0.07$ & 46.56 \\
Flounder & $25.31 \pm 0.49$ & $6.9 \pm 1.0$ & $99.25 \pm 0.49$ & 27.26 \\
Salmon & $25.56 \pm 0.46$ & $3.09 \pm 0.31$ & $99.0 \pm 0.14$ & 12.10 \\
Halibut & $29.09 \pm 0.15$ & $14.94 \pm 1.33$ & $99.55 \pm 0.21$ & 51.36 \\
Herring & $31.92 \pm 0.56$ & $13.83 \pm 0.9$ & $99.9 \pm 0.001$ & 43.34 \\
\hline
\end{tabular}

* Arithmetic mean \pm standard deviation $(n=5)$.

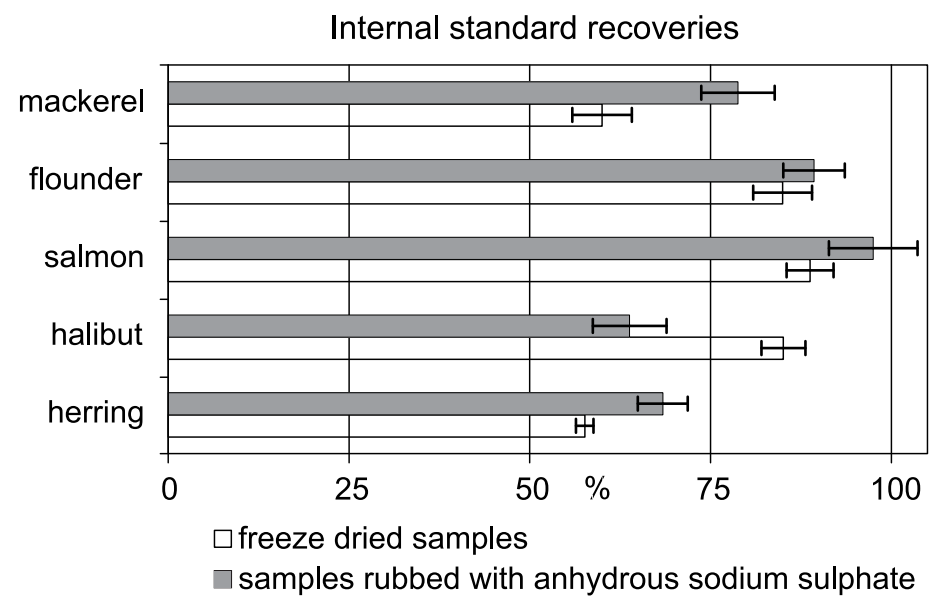

Fig. 3. Recoveries of surrogate (decachlorobiphenyl, PCB 209) in the muscle tissue of various fish species prepared for analysis with two methods: freeze drying and rubbing with anhydrous sodium sulphate, $(n=5)$ 
ํㅡㄹ

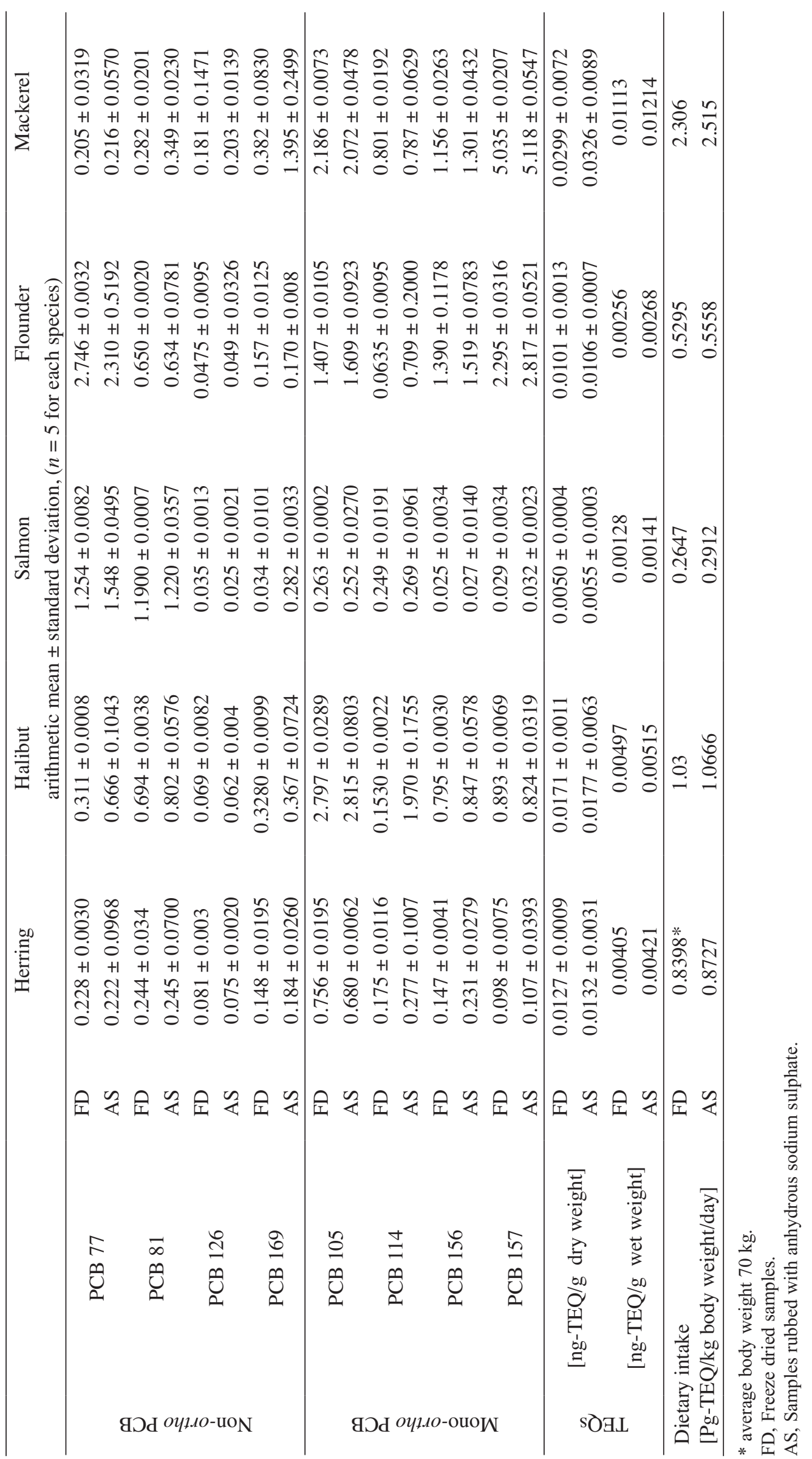


อ

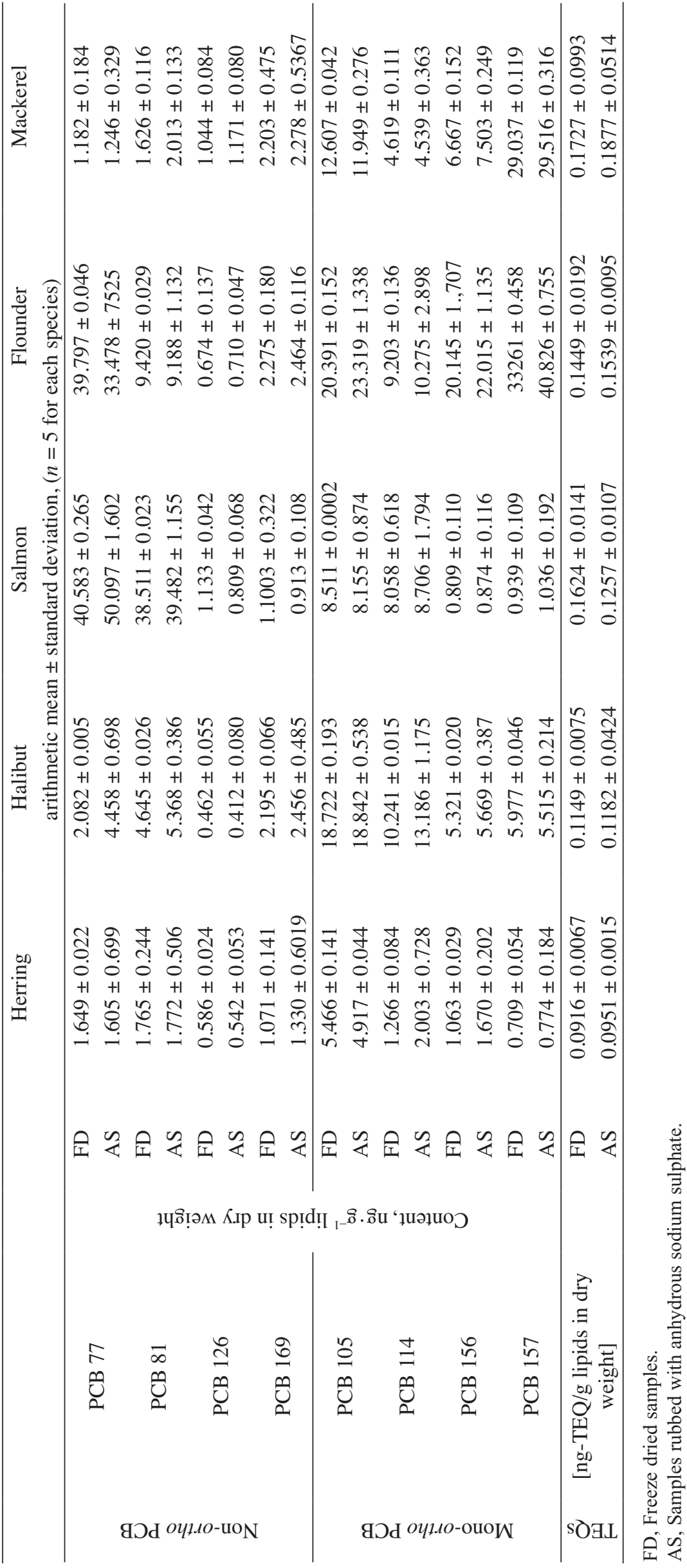


Table 4

Coefficients of variation CV [\%] in the muscle tissue of various fish species prepared with two methods: freeze drying and rubbing with anhydrous $\mathrm{Na}_{2} \mathrm{SO}_{4},(n=5$ for each species $)$

\begin{tabular}{lcccccccc}
\hline \multirow{2}{*}{ Fish species } & \multicolumn{10}{c}{ CV [\%] } \\
\cline { 2 - 10 } & PCB 77 & PCB 81 & PCB 126 & PCB 169 & PCB 105 & PCB 114 & PCB 156 & PCB 157 \\
\hline Herring & 1.30 & 6.66 & 2.38 & 1.29 & 2.64 & 6.59 & 3.65 & 5.89 \\
Halibut & 2.63 & 0.11 & 1.94 & 4.07 & 3.62 & 1.23 & 1.07 & 7.14 \\
Salmon & 3.25 & 2.93 & 3.82 & 4.77 & 6.02 & 4.13 & 3.53 & 4.37 \\
Flounder & 0.43 & 4.70 & 1.57 & 4.58 & 2.59 & 0.70 & 1.72 & 4.01 \\
Mackerel & 3.72 & 4.81 & 1.02 & 4.68 & 0.26 & 1.71 & 1.60 & 2.91 \\
\hline & & & Samples rubbed with anhydrous sodium sulphate & & \\
\hline Herring & 1.36 & 1.23 & 6.15 & 4.02 & 0.92 & 3.29 & 6.24 & 3.88 \\
Halibut & 5.07 & 2.47 & 1.48 & 4.88 & 2.76 & 4.42 & 3.99 & 4.22 \\
Salmon & 3.20 & 2.93 & 4.43 & 4.76 & 4.49 & 4.47 & 4.01 & 7.27 \\
Flounder & 3.43 & 2.10 & 2.77 & 4.38 & 5.08 & 3.46 & 3.87 & 1.03 \\
Mackerel & 4.58 & 4.95 & 0.54 & 0.92 & 3.10 & 5.07 & 4.91 & 3.65 \\
\hline
\end{tabular}
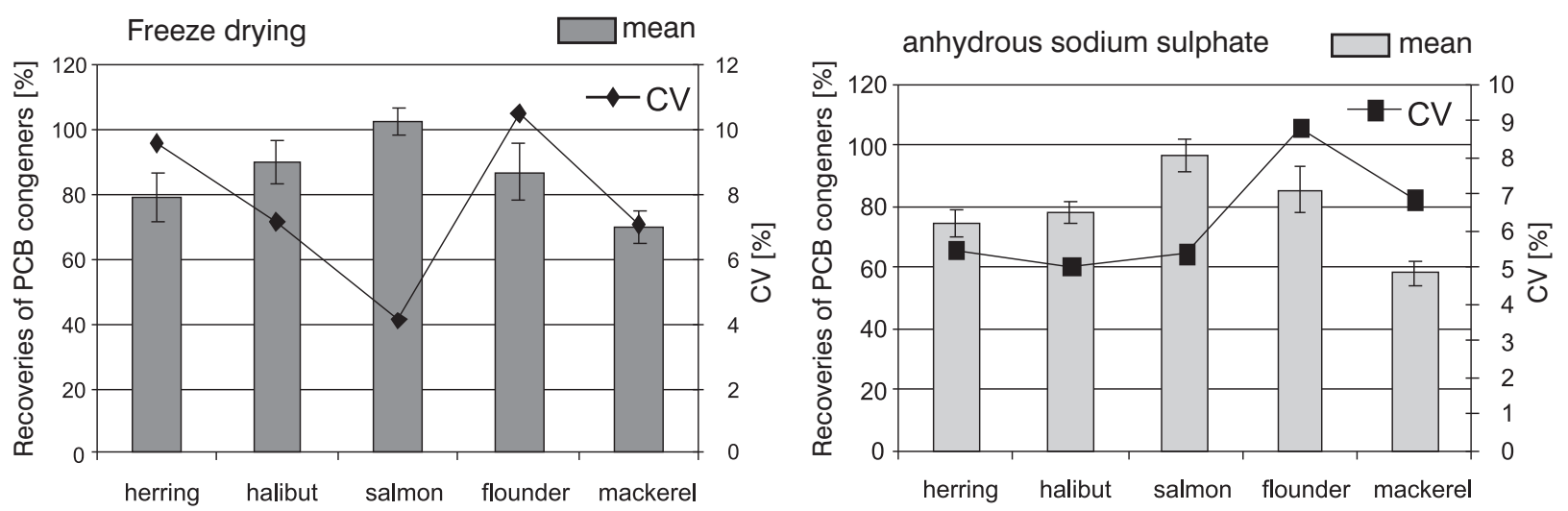

Fig. 4. Mean recoveries ( \pm standard deviation) of non-ortho and mono-ortho PCB congeners in the muscle tissue of five fish species prepared for analysis with two methods: freeze drying and rubbing with anhydrous sodium sulphate, $(n=5)$; CV, coefficient of variation

Coefficients of variation (CV) were calculated for the data obtained in the study (Table 4):

$\mathrm{CV}=\mathrm{RDS} \cdot 100 \%$, where $\operatorname{RDS}=\frac{\mathrm{s}}{\bar{x}}$

$\mathrm{s}$, standard deviation; $\bar{x}$, mean concentration of PCB congener.

In the freeze dried samples $\mathrm{CV}$ varied between $0.11 \%$ (PCB 81, halibut) and 7.14\% (PCB 157, halibut). In the samples rubbed with $\mathrm{Na}_{2} \mathrm{SO}_{4} \mathrm{CV}$ ranged from $0.54 \%$ (PCB 126, mackerel) to $7.27 \%$ (PCB 157, salmon).

Additionally, toxic equivalents TEQs were calculated on the basis of the toxic equivalency factors TEFs (Van den Berg et al. 2006) and PCB concentrations in the samples. For the freeze dried samples, TEQs ranged from $0.0050 \mathrm{ng}$-TEQ $\cdot \mathrm{g}^{-1} \mathrm{~d}$.w. in salmon to $0.0299 \mathrm{ng}$-TEQ $\cdot \mathrm{g}^{-1}$ d.w. in mackerel, and for the samples rubbed with anhydrous sodium sulphate they were from $0.0055 \mathrm{ng}$-TEQ $\mathrm{g}^{-1} \mathrm{~d}$.w. in salmon to $0.0326 \mathrm{ng}$-TEQ $\cdot \mathrm{g}^{-1} \mathrm{~d}$.w. in mackerel (Fig. 5). When converted into lipids, the highest TEQ values were found, in case of both methods, in mackerel, and the lowest in herring (Fig. 5).

\section{DISCUSSION}

PCBs penetrate into fish body mainly through the gills, and also through the alimentary tract, their bioaccumulation coefficients in organs being high, even to several thousands (Kulkarni and Kavara 1990, Strandberg et al. 1998, Ruus et al. 1999, Crimmins et al. 2002). The real toxicological hazard is posed by dioxin-like PCBs, and fortunately these PCB congeners occur in fish bodies in 

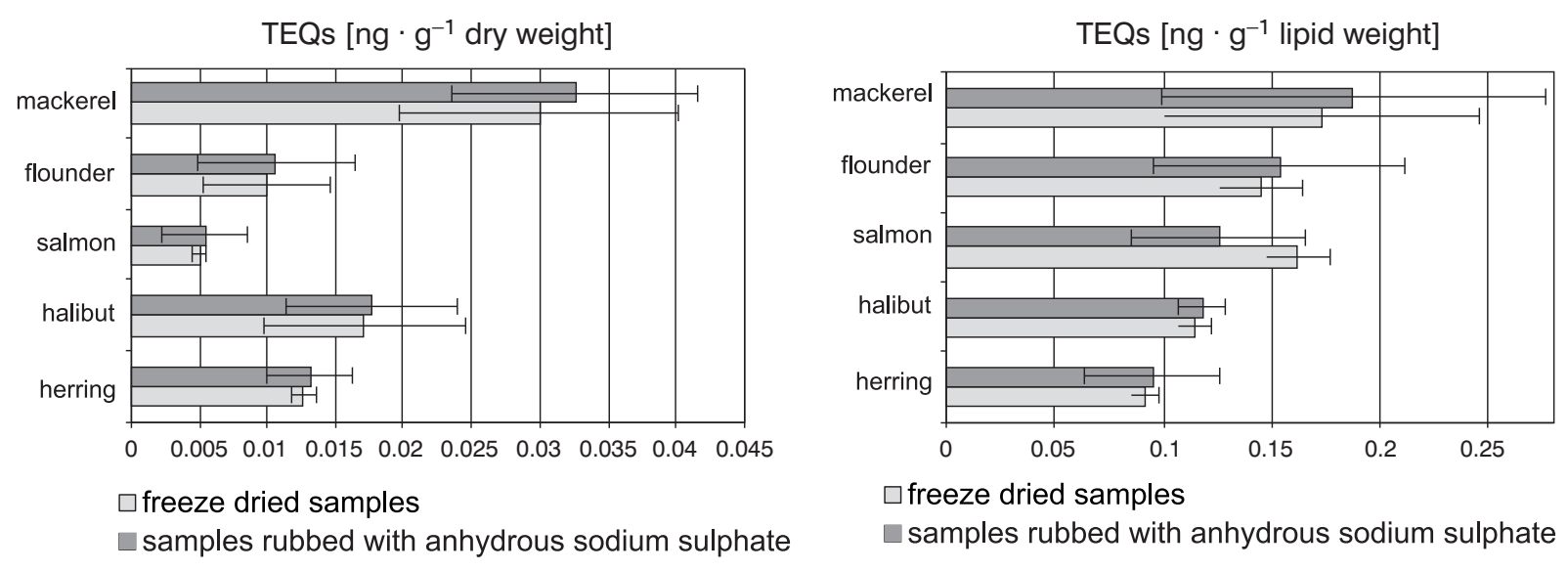

Fig. 5. Equivalent toxicity (TEQ) of muscle tissue of various fish species prepared with two methods: freeze drying and rubbing with anhydrous sodium sulphate; a) $\mathrm{ng} \cdot \mathrm{g}^{-1}$ dry weight, b) $\mathrm{ng} \cdot \mathrm{g}^{-1}$ lipid weight, $(n=5)$

much lower concentrations than the indicator PCBs (i.e., PCB 180, PCB 153) (Falandysz 2002). Adequate procedures of sample preparation, assuring the lowest possible losses of analytes, are necessary for accurate estimation of the risk of consuming contaminated food products. Special attention should be focused on fish, as the aquatic animals are particularly exposed to PCB accumulation in their tissues.

The study of Berdié and Grimalt (1998) revealed, that PCB content in freeze dried fish muscle tissue was significantly lower than in the same tissue dried by rubbing with anhydrous sodium sulphate. Moreover, Falandysz (1982) observed that freeze drying reduced PCB content in contaminated eggs by 25 percentage points, and in contaminated shrimps by nearly 50 percentage points. These data imply, that during freeze drying significant amounts of PCB compounds evaporate from the dried matrices.

De Voogt et al. (2000) obtained PCB recoveries in freeze dried bivalves on the level of $53 \pm 36 \%$. However Thomas et al. (1998) reported, that recoveries of 53 PCB congeners in freeze dried milk samples amounted from 69 to $96( \pm 10)$ percentage points.

Losses of PCBs during sublimation drying depend mainly on the properties of particular PCB congeners and their concentrations in the dried product. Other important factors are the properties of the product: fat content, physicochemical properties (e.g., density, viscosity) and changes of the product's structure produced by freeze drying process (Falandysz 1982).

Our study confirmed previous reports of other researchers to a large extent. The obtained values are especially similar to PCB recoveries reported by Thomas et al. (1998). The authors also claim, that reliability of an analytical method is confirmed by coefficients of variation lower than $30 \%$. In our study $\mathrm{CV}$ values were lower than $8 \%$.

Toxic equivalents TEQs calculated for the freezedried samples ranged from $0.0050 \mathrm{ng}$-TEQ $\cdot \mathrm{g}^{-1}$ dry weight (d.w.) in salmon to $0.0299 \mathrm{ng}$-TEQ $\cdot \mathrm{g}^{-1}$ dry weight in mackerel. In the samples rubbed with anhydrous sodium sulphate, the highest TEQ values were also in mackerel (0.0326 ng-TEQ $\cdot \mathrm{g}^{-1}$ d.w.), and the lowest in salmon (0.0055 ng-TEQ $\cdot \mathrm{g}^{-1}$ d.w.).

According to the Commission Regulation (EC) No. 1881/2006 of 19 December 2006 (Anonymous 2006), the maximum level of dioxin-like PCBs, calculated as the difference between the level of the sum of dioxins and dioxin-like PCBs (WHO-PCDD/F-PCB-TEQ) and the level of dioxins (WHO-PCDD/F-TEQ), in the muscle meat of fish and fishery products, excluding eel, is set at $4.0 \mathrm{pg}$-TEQ $\cdot \mathrm{g}^{-1}$ fresh weight, and in the muscle meat of eel and products thereof $-8 \mathrm{pg}$-TEQ $\cdot \mathrm{g}^{-1}$ fresh weight. A comparison of the data obtained in the study and the maximum levels set by the Regulation indicated, that only the muscle meat of mackerel contained more than $4 \mathrm{pg}$-TEQ $\cdot \mathrm{g}^{-1}$ fresh weight (Table 2).

Tolerable weekly intake (TWI) for dioxins and dioxinlike PCBs is $14 \mathrm{pg}_{\text {WHO-TEQ }} \cdot \mathrm{kg}^{-1}$ body weight, which establishes TDI (tolerable daily intake) on the level of $2 \mathrm{pg}_{\text {WHO-TEQ }} \cdot \mathrm{kg}^{-1}$ body weight (OJ L 364 2006). In Poland, annual consumption of fish (marine and freshwater) and fishery products per one person averaged $4.8 \mathrm{~kg}$ in 2002, and $5.3 \mathrm{~kg}$ in 2003 (Anonymous 2004). This establishes daily consumption on the level of $0.0145 \mathrm{~kg}$ per day per person. On the basis of the calculated TEQs and the daily consumption of fish and fishery products per person $(0.0145 \mathrm{~kg})$, were estimated the PCB intake from the consumed fish. For the freeze dried fish the dietary intake amounted to $0.2647-2.306 \mathrm{pg}$-TEQ $\cdot \mathrm{kg}^{-1}$ body weight per day, and for the samples dried with anhydrous sodium sulphate $0.2912-2.515 \mathrm{pg}$-TEQ $\cdot \mathrm{kg}^{-1}$ body weight per day.

\section{CONCLUSIONS}

The analysed non-ortho and mono-ortho PCB congeners have been detected in all the examined fish species.

PCB 157 was the most abundant congener, its concentrations (dry weight basis) being the highest in mackerel muscle meat. The lowest concentrations (dry weight basis) were observed for PCB 126 in the salmon meat.

Toxicity equivalents (TEQs) calculated for the examined fish species ranged between $1.278 \mathrm{pg}$-TEQ $\cdot \mathrm{g}^{-1}$ w.w. 
for salmon (freeze dried) and $12.14 \mathrm{pg}-\mathrm{TEQ} \cdot \mathrm{g}^{-1} \mathrm{~W} . \mathrm{w}$. for mackerel (rubbed with $\mathrm{Na}_{2} \mathrm{SO}_{4}$ ).

The results obtained with both methods have not differed significantly $(P<0.05)$, although freeze drying resulted in slightly higher losses of PCB congeners. The values of coefficient of variation below $8 \%$ confirm good precision of both methods applied. Despite of slightly smaller recoveries, freeze drying can be applied because of solvent saving and easier sample preparation.

\section{REFERENCES}

Anonymous 2004. Statistical Yearbook of Maritime Economy. Central Statistical Office in Szczecin. Warszawa-Szczecin 2004.

Anonymous 2006. Commission Regulation (EC) No 1881/2006 of 19 December 2006 setting maximum levels of certain contaminants in foodstuffs. Official Journal of the European Union L 364/5 http://eur-lex.europa.eu/LexUriServ/site/en/ /oj/2006/1_364/1_36420061220en00050024.pdf.

Atuma S.S., Aune M., Bergh A., Wicklund-Glynn A., Darnerud P.O., Larsson L., Olsson M., Sandstrom O. 1998. Polychlorinated biphenyls in salmon (Salmo salar) from the Swedish east coast. Organohalogen Compounds 39: 153-156.

Baars A.J., Bakker M.I., Baumann R.A., Boon P.E., Freijer J.I., Hoogenboom L.A.P., Hoogerbrugge R., van Klaveren J.D., Liem A.K.D., Traag W.A., de Vries J. 2004. Dioxins, dioxin-like PCBs and non-dioxin-like PCBs in foodstuffs: occurrence and dietary intake in the Netherlands. Toxicology Letters 151: 51-61.

Berdié L., Grimalt J.O. 1998. Assessment of the sample handling procedures in a labor-saving method for analysis of organochlorine copmounds in a large number of fish sample. Journal of Chromatography A 823: 373-380.

Brzeziński J. 2002. Toksykologia pestycydów. [Toxicology of pesticides.] Pp. 605-660. In: Seńczuk W. (ed.) Toksykologia. [Toxicology.] PZWL, Warszawa. [In Polish.]

Ciereszko W., Tomza A., Witczak A. 2004. Zawartości wybranych kongenerów polichlorowanych biphenyli (PCB) w konserwach z tuńczyka. [The contents of selected of polychlorinated biphenyls congeners (PCB) in tinned tuna.] Acta Scientiarum Polonorum; Technologia Alimentaria 3 (2): 57-62.

Ciereszko W., Witczak A. 2002. Concentration of PCBs and selected pesticides in bottom sediments, zebra mussel and in some more important fish species of the Szczecin Lagoon. Acta Ichthyologica et Piscatoria 32: 35-40.

Ciereszko W. 2002. Polychlorinated hydrocarbons in fishes, blue mussel (Mytilus edulis), and bottom sediments of the south-western Baltic Sea. Acta Ichthyologica et Piscatoria 32: 127-135.

Crimmins B.S., Doelling Brown P., Kelso D.P., Foster G.D. 2002. Bioaccumulation of PCBs in aquatic biota from a tidal freshwater marsh ecosystem. Archives of Environment Contamination and Toxicology 42: 396-404.

Davis J.A., Hetzel F., Oram J.J., McKee L.J. 2007. Polychlorinated biphenyls (PCBs) in San Francisco Bay. Environmental Research 105: 67-86. de Voogt P., van der Wielen F.W.M., Govers H.A.J. 2000. Freeze-drying brings about errors in polychlorinated biphenyl recovery calculations. Trends in Analytical Chemistry 19: 292-299.

Falandysz J. 1982. Wpływ przetwarzania na zawartość polichlorowanych dwufenyli w produktach spożywczych. [The effect of processing on concentrations of polychlorinated biphenyls in foodstuffs.] Roczniki Państwowego Zakładu Higieny 33: 27-33. [In Polish.]

Falandysz J., Wyrzykowska B., Puzyn T., Strandberg L., Rappe C. 2002. Polychlorinated biphenyls (PCBs) and their congener-specific accumulation in edible fish from the Gulf of Gdańsk, Baltic Sea. Food Additives and Contaminants 19: 779-795.

Kulkarni M.G., Kavara A.H. 1990. A pharmacokinetic model for the disposition of polychlorinated biphenyls (PCBs) in channel catfish. Aquatic Toxicology 16: 141-150.

Paasivirta J., Koistinen J., Rantio T., Vourinen P.J. 1994. Persistent organochlorine compounds in Arctic and Baltic fish. Organohalogen Compounds 20: 529-534.

Roose P., Cooreman K., Vyncke W. 1998. PCBs in cod (Gadus morhua), flounder (Platichthys flesus), blue mussel (Mytilus edulis) and brown shrimp (Crangon crangon) from the Belgian continental shelf: Relation to biological parameters and trend analysis. Chemosphere 37: 2199-2210.

Ruus A., Ugland K.I., Espeland O., Skaare J.U. 1999. Organochlorine contaminants in a local marine food chain from Jarfjord, Northern Norway. Marine Environmental Research 48: 131-146.

Safe S. 1994. Polichlorinated biphenyls (PCBs) environmental impact, biochemical and toxic responses, and implications for risk assessment. CRC Critical Review of Toxicology 24: 87-149.

Strandberg B.O., Van Bavel B., Bergqvist P.-A., Broman D., Ishaq R., Näf C., Pettersen H., Rappe C. 1998. Occurrence, sedimentation, and spatial variations of organochlorine contaminants in settling particulate matter and sediments in the Northern Part of the Baltic Sea. Environmental Science and Technology 32: 1754-1759.

Thomas G.O., Sweetman A.J., Parker C.A. Kreibich H., Jones K.C. 1998. Development and validation of methods for the trace determination of PCBs in biological matrices. Chemosphere 36: 2447-2459.

Van den Berg M., Birnbaum L.S., Denison M., De Vito M., Farland W., Feeley M., Fiedler H., Hakansson H., Hanberg A., Haws L., Rose M., Safe S., Schrenk D., Tohyama C., Tritscher A., Tuomisto J., Tysklind M., Walker N., Peterson R.E. 2006. The 2005 World Health Organization reevaluation of human and mammalian toxic equivalency factors for dioxins and dioxin-like compounds. Toxicological Sciences 93: 223-241.

Received: 8 February 2008 Accepted: 29 April 2008 Published electronically: 20 June 2008 